\title{
SPEVY OMŠOVÉHO ORDINÁRIA V GRADUALE CASSOVIENSE
}

\section{Rastislav ADAMKo}

prof. ThDr. Rastislav Adamko, PhD.; Katolícka univerzita v Ružomberku, Pedagogická fakulta, Katedra hudby; e-mail: rastislav.adamko@ku.sk

ORCID: 0000-0003-4769-9368

\section{Abstract}

The two-volume manuscript Graduale Cassoviense sign. Clmae 172a et 172b, from the early $16^{\text {th }}$ century, is a diocesan missal manuscript which at its time of origin was designed for the everyday Mass liturgy. The liturgico-musical tradition concealed behind the choice of chants, modal digressions, and textual and melodic variants, has its roots in the Central European milieu. A common Central European tradition forms an essential part of the significant elements. To an extent they were familiar also in the Estergom tradition, but investigation of the present sources reveals many which do not occur in Estergom sources. The Košice Gradual contains several melodic variants hitherto not known from other sources. This is manifested particularly in late medieval chants, such as chants from the Ordinary of the Mass. From this standpoint, the gradual examined here is an important example of unique late-medieval chants.

Key words: gradual, chants from the Mass Ordinary, musico-liturgical tradition, melodic variants, tropes

Graduale Cassoviense - Košický graduál je monumentálny ${ }^{1}$ dvojzväzkový rukopis zo začiatku 16. storočia toho času uchovávaný v Széchényiho knižnici v Budapešti so signatúrou Clmae 172a et 172b (dalej Ca I a Ca II). Monumentálne rozmery má aj písmo, aj notácia, ktorú možno charakterizovat ako métsko-gotický notačný systém ovplyvnený českou a nemeckou gotickou chorálnou notáciou. ${ }^{2}$

1 Kódex má pozoruhodné rozmery: I. zväzok: $715 \times 560 \mathrm{~mm}$, II. zväzok: $725 \times 560 \mathrm{~mm}$. Na svete sa za najväčšiu rukopisnú knihu považuje tzv. Codex gigas, ktorý má na porovnanie rozmery 890 $\times 490 \mathrm{~mm}(80 \mathrm{~kg})$.

2 Opis týchto notácií v prameňoch z teritória dnešného Slovenska uskutočnila VESELOVSKÁ, Eva: Catalogus fragmentorum cum notis musicis medii aevi e civitatibus Modra et Sanctus Geor- 
Stredoveké Košice boli známe ako pútnické miesto, kam putovali veriaci z celej strednej Európy, ktorí túžili vidiet relikviu Kristovej Krvi. ${ }^{3}$ Novopostavený Dóm sv. Alžbety, aj ked' nebol biskupským chrámom, si vyžadoval aj nové liturgické knihy. Na tému času vyhotovenia graduálu existovalo niekolko rôznych názorov. Podla gvardiána košického konventu františkánov Vincenta Blaha (autora indexu k rukopisu v roku 1782) rukopis vznikol v 15. storočí za panovania krála Mateja Korvína. Edita Hofmannová však v II. zväzku graduálu (na f 273) našla v jednej z malovaných iniciál dopísaný rok $1518 .{ }^{4}$ Nie je zatial' dokázané, že rukopis bol vyhotovený pre Košice alebo dokonca priamo v Košiciach. ${ }^{5}$ Podla jednej z hypotéz mohol byt graduál spolu s inými cennostami do Košíc prevezený z Vel'kého Varadína, ktorý bol v tom čase v 16. storočí obsadený Turkami. ${ }^{6}$ Graduál je hodnotný aj po výtvarnej stránke, pretože obsahuje viaceré mal’ované iniciály, ktoré prezrádzajú vel'kú mieru umeleckej vyspelosti a originality svojho tvorcu. ${ }^{7}$

Graduál je rozdelený tradičným spôsobom na zimnú a letnú čast'. V každom zväzku možno identifikovat’ pät kapitol, ktoré nie sú formálne vyčlenené rubrikami či nadpismi. Možno ich však tradične označit pojmami zaužívanými v rímskej liturgii - I. Ordinarium missae, II. Proprium de tempore, III. Proprium de sanctis, IV. Commune sanctorum, V. Pro defunctis, VI. Prosarium. V druhom zväzku je zmena v poradí kapitol, pričom Pro defunctis je hned' po Propriu de tempore (Tabul'ka 1).

Tabulka 1: Štruktúra obsahu rukopisu Ca I a Ca II

\begin{tabular}{|c|c|c|}
\hline & $\mathrm{Ca} \mathrm{I}$ & Ca II \\
\hline I. Ordinarium missae & $1 \mathrm{r}-43 \mathrm{r}$ & $1 \mathrm{r}-48 \mathrm{v}$ \\
\hline II. Proprium de tempore & $45 \mathrm{r}-242 \mathrm{v}$ & $49 \mathrm{r}-125 \mathrm{r}$ \\
\hline III. Proprium de sanctis & $\begin{array}{c}\text { 243r-310r (Vig. Andreae - } \\
\text { Assumptio BMV) }\end{array}$ & 147r-243v (Nerei - vig. Andreae) \\
\hline IV. Commune sanctorum & $310 \mathrm{r}-329 \mathrm{v}$ & $244 \mathrm{r}-272 \mathrm{v}$ \\
\hline V. Pro defunctis & $330 \mathrm{r}-342 \mathrm{v}$ & $130 \mathrm{r}-146 \mathrm{v}$ \\
\hline VI. Prosarium & $344 v-424$ & $273 r-374 v$ \\
\hline
\end{tabular}

gius I. Bratislava : Institut für Musikwissenschaft der Slowakischen Akademie der Wissenschaften, 2008, s. 48-61.

3 ZUBKO, Peter: Kult Svätej Krvi v Košiciach : Rozprávanie o stratených stredovekých relikviách. Košice : Viliam Ščiavnický, 2012, s. 19-70.

4 HOFMANN, Edit: A Nemzeti Múzeum Széchényi Könyvtárának illuminált kéziratai. In: Magyar Könyvszemle, 1927, č. 34, zošit 1-2, s. 41.

5 BERKOVITS, Ilona: A Kassai-graduale és a XVI. századi kassai festészet. In: Emlékkönyv Gerevich Tibor születésének 60. Évfordulójára. Budapest, 1942, s. 68-88; GÜNTHEROVÁ, Alžbeta - MIŠIANIK, Ján: Stredoveká knižná malba na Slovensku. Bratislava : Slovenské vydavatelstvo krásnej literatúry, 1961, s. 62-63, č. 58.

6 BALOGH, Jolán: Varadinum, Várad vára. In: Müvészettörténeti Füzetek 13/2. Budapest : Akadémiai Kiadó, 1982, s. 298-299; KISS, Gábor: A true ‘Central European’ manuscript: the Graduale Cassoviense from 1518. In: ADAMKO, Rastislav (ed.): Musica Mediaeva Liturgica II. : Zborník príspevkov z muzikologickej konferencie. Ružomberok: Verbum, 2016, s. 77-89.

7 HOFMANN, Ref. 4; GÜNTHEROVÁ - MIŠIANIK, Ref. 5. 
Zimná čast' (Ca I) obsahuje spevy adventného, ${ }^{8}$ vianočného, pôstneho a vel'konočného obdobia až po formulár slávnosti Božieho Tela. Proprium de sanctis sa v ňom začína vigíliou sviatku sv. apoštola Ondreja (29. XI.) a končí sa sviatkom Nanebovzatia Panny Márie (15. VIII.). Spoločná čast’ svätých obsahuje spevy na sviatky Panny Márie, evanjelistov, apoštolov, jedného a viacerých mučeníkov, vyznávačov a panien.

Letná čast̉ graduálu (Ca II) v kapitole Proprium de tempore sa začína nedelou Zoslania Ducha Svätého, pokračuje slávnostami Najsvätejšej Trojice, Božieho Tela, nedelami Post Trinitatem až po 23. nedelu. Ďalej je tu formulár sviatku Posvätenia chrámu a omše za zosnulých. Formulár Dedicatio ecclesiae je v Ca II hned' po temporáli, a nie až po sanktoráli ako v Ca I. Proprium de sanctis sa v Ca II pravdepodobne (bez rubriky) začína sviatkom Nerei et soc. (12. V.) a končí sa vigíliou sviatku sv. apoštola Ondreja (29. XI.). Commune sanctorum má takú istú štruktúru ako v Ca I, avšak s čiastočne iným repertoárom.

Obidva zväzky majú podobný repertoár spevov omšového ordinária, spevov na omše za zosnulých a sekvencií. Sekvencie sú v jednotlivých zväzkoch Košického graduálu rozdielne, čo vyplýva $\mathrm{z}$ odlišností v sviatkoch svätých, ktoré sa v danom zväzku nachádzajú.

Kyriale v prvom i druhom zväzku graduálu je umiestnené hned’ na začiatku oboch rukopisov, čo nekorešponduje s tradíciou ostatných uhorských rukopisov. Tie uvádzajú spevy omšového ordinária na konci liturgických kódexov v tzv. apendixe, kde sú zvyčajne umiestnené spevy alleluja a sekvencie. ${ }^{9}$ Prax umiestňovania Kyriale na začiatku rukopisu bola rozšírená $\mathrm{v}$ Pollsku, v prostredí diecéznom, ale i reholnom (strážcovia Božieho hrobu z Nysy, regulárni kanonici zo Żagania, paulíni, minoriti). ${ }^{10}$ Prehlad celej štruktúry ordinária $v$ oboch dieloch graduálu s označením jednotlivých spevov podla príslušných katalógov je uvedený v nasledujúcich tabulkách 2 až 5.

$8 \quad$ V súčasnosti sa pre defekt rukopisu začína piatkom po 3. adventnej nedeli.

9 SZENDREI, Janka: Graduale Strigoniense I. : Musicalia Danubiana Vol. 12*. Budapest : Magyar Tudományos Akadémia Zenetudomány Intézet, 1993, s. 170.

10 PIKULIK, Jerzy: Indeks śpiewów Ordinarium missae w graduałach polskich do $1600 \mathrm{r}$. In: Muzyka religijna w Polsce, roč. 2. Warszawa, 1978, s. 144-145. 
Tabulka 2: Spevy Kyrie v Ca I a II

\begin{tabular}{|c|c|c|c|c|c|c|}
\hline Mel. ${ }^{11}$ & Ca I & Ca II & Modus & LU & Trópus & Rubrika v Ca I \\
\hline K7 & $16 \mathrm{r}$ & $23 r$ & $\mathrm{E}$ & - & - & In Quadragesima \\
\hline K16 & $9 \mathrm{r}$ & $15 \mathrm{r}$ & $\mathrm{D}$ & $\mathrm{XI}$ & - & De martyribus \\
\hline K18 & - & $2 \mathrm{v}$ & $\mathrm{D}$ & IV & - & - \\
\hline K39 & - & $5 r$ & G & I & - & - \\
\hline \multirow[t]{2}{*}{ K48 } & $1 \mathrm{r}$ & $1 \mathrm{v}$ & $\mathrm{E}$ & II & $\begin{array}{l}\text { Fons bonitatis } \\
\text { Sacerdos summe } \\
\text { (margo v Ca II) }\end{array}$ & - \\
\hline & - & $2 \mathrm{r}$ & $\mathrm{E}$ & II & Virginitatis amator & - \\
\hline K56 & - & $17 \mathrm{r}$ & $\mathrm{F}$ & - & - & - \\
\hline K58a & $6 r$ & $12 \mathrm{r}$ & G & - & - & $?$ \\
\hline K68 & $7 v$ & $13 \mathrm{v}$ & $+\mathrm{D}$ & XIV & - & De apostolis \\
\hline K78 & $1 \mathrm{r}$ & $1 \mathrm{r}$ & $\mathrm{G}$ & $\mathrm{V}$ & Magne Deus potentiae & - \\
\hline K95 & $4 \mathrm{r}$ & $10 \mathrm{r}$ & $\mathrm{F}$ & VIII & - & De BMV \\
\hline K96 & $10 \mathrm{v}$ & - & $\mathrm{F}$ & Sanctus VIII & - & De confesoribus \\
\hline K97 & - & $6 \mathrm{v}$ & $\mathrm{F}$ & - & - & - \\
\hline K107 & $16 \mathrm{v}$ & $24 \mathrm{r}$ & $\mathrm{F}$ & - & - & Temp. passionis \\
\hline K108 & $17 \mathrm{r}$ & $24 \mathrm{v}$ & $\mathrm{F}$ & - & - & Feriale de Passione \\
\hline K111 & $4 \mathrm{v}$ & $10 \mathrm{v}$ & $\mathrm{F}$ & - & - & Sanctorum lumen \\
\hline K126 & $5 r$ & $11 \mathrm{v}$ & $\mathrm{F}$ & - & - & Idem (De BVM) \\
\hline K131a & $5 v$ & $12 \mathrm{r}$ & $\mathrm{F}$ & - & - & Idem? \\
\hline K132 & $5 r$ & $11 \mathrm{r}$ & $\mathrm{F}$ & Ad libitum VIII & - & De BMV \\
\hline K144 & $14 \mathrm{v}$ & $21 \mathrm{v}$ & $E$ & - & - & Feriale \\
\hline K148? & - & $\operatorname{lp} 6 \mathrm{v}$ & $\mathrm{E}$ & - & - & - \\
\hline K149 & $4 \mathrm{r}$ & $10 \mathrm{v}$ & $\mathrm{E}$ & - & - & Idem (De BVM) \\
\hline K149a & $5 \mathrm{v}$ & - & $\mathrm{E}$ & - & - & $?$ \\
\hline K151 & $12 \mathrm{r}$ & $18 \mathrm{v}$ & $\mathrm{E}$ & - & - & $?$ \\
\hline K171 & $2 r$ & $7 \mathrm{v}$ & $\mathrm{D}$ & IX & - & - \\
\hline K201 & $17 \mathrm{r}$ & $24 \mathrm{v}$ & $\mathrm{D}$ & - & - & Feriale rogationum \\
\hline K212 & $16 \mathrm{r}$ & $23 \mathrm{v}$ & $\mathrm{E}$ & - & - & In Adventu \\
\hline K212a & $16 \mathrm{v}$ & $23 \mathrm{v}$ & $\mathrm{E}$ & - & - & Feriale in Adventu \\
\hline K217 & $13 \mathrm{v}$ & - & $\mathrm{D}$ & XVI & - & Dominicale majus \\
\hline K217 & $2 \mathrm{r}$ & - & $\mathrm{D}$ & XVI & - & - \\
\hline $\mathrm{K} 217 \mathrm{a}$ & $16 \mathrm{r}$ & $23 r$ & $\mathrm{D}$ & XVI (variant) & - & Idem (Feriale) \\
\hline $\mathrm{K} 217 \mathrm{~b}$ & - & $20 \mathrm{r}$ & $\mathrm{D}$ & XVI (variant) & - & - \\
\hline
\end{tabular}

Legenda (platí pre tabulky $2-5$ ):

A - Agnus Dei

BVM - Beata Virgo Maria

G - Gloria

$\mathrm{K}-$ Kyrie

lp - lacuna post

LU - Liber usualis, omšové ordinária

$\mathrm{S}$ - Sanctus

? - neznámy údaj spôsobený defektom kódexu

11 LANDWEHR-MELNICKI, Margaretha: Das einstimmige Kyrie des lateinischen Mittelalters. Regensburg, 1955. 
Tabulka 3: Spevy Gloria v Ca I a II

\begin{tabular}{|c|c|c|c|c|c|c|}
\hline Bos. ${ }^{12}$ & $\mathrm{Ca} \mathrm{I}$ & Ca II & Modus & LU & Trópus & Rubrika v Ca I \\
\hline G5 & $6 r$ & $12 \mathrm{v}$ & $\mathrm{F}$ & - & $\begin{array}{l}\text { Jesu Christe altissime } \\
\text { (iba v Ca II) }\end{array}$ & $?$ \\
\hline G11 & $14 r ?$ & $20 \mathrm{v}$ & $\mathrm{D}=\mathrm{tp} 2 \downarrow \mathrm{E}$ & XIV & - & Dominicale majus \\
\hline G12 & - & $5 r$ & $\mathrm{G}$ & I & - & - \\
\hline G19 & $9 \mathrm{r}$ & $15 \mathrm{r}$ & $\mathrm{D}$ & II & $\begin{array}{l}\text { Fili unigenite salus } \\
\text { nostra (iba v Ca II) }\end{array}$ & De martyribus \\
\hline G21 & $17 \mathrm{v}$ & $25 \mathrm{r}$ & G & - & Jesu Christe altissime & Feriale rogationum \\
\hline G23 & $2 \mathrm{r}$ & $8 \mathrm{r}$ & G & IX & Spiritus et almae & - \\
\hline G24a & - & $3 r$ & G & Ad libitum I (variant) & - & - \\
\hline G37 & $11 \mathrm{r}$ & $17 \mathrm{v}$ & $\mathrm{F}$ & - & $\begin{array}{l}\text { Jesu Christe altissime } \\
\text { (iba v Ca II) }\end{array}$ & De confesoribus \\
\hline G37? & - & $\operatorname{lp} 6 \mathrm{v}$ & $\mathrm{F}$ & - & - & - \\
\hline G43 & $15 \mathrm{r}$ & $22 \mathrm{r}$ & $\mathrm{E}$ & $\mathrm{XV}$ & Jesu Christe altissime & Feriale \\
\hline G45 & - & $7 \mathrm{r}$ & $\mathrm{E}$ & - & - & - \\
\hline G48 & $13 r ?$ & $19 \mathrm{r}$ & $\mathrm{E}$ & - & - & $?$ \\
\hline G56 & $7 \mathrm{v}$ & $14 \mathrm{r}$ & $\mathrm{E}$ & IV & $\begin{array}{l}\text { Jesu Christe altissime } \\
\text { (iba v Ca II) }\end{array}$ & De apostolis \\
\hline
\end{tabular}

Tabulka 4: Spevy Sanctus v Ca I a II

\begin{tabular}{|c|c|c|c|c|c|c|}
\hline Than..$^{13}$ & $\mathrm{Ca} \mathrm{I}$ & Ca II & Modus & LU & Trópus & Rubrika v Ca I \\
\hline S19a & $23 r$ & $30 \mathrm{r}$ & $\mathrm{F}$ & - & - & Ad placitum \\
\hline S29 & 24 & - & $\mathrm{F}$ & IX & Mariae filius & De BVM \\
\hline S29a & - & $31 \mathrm{v}$ & $\mathrm{F}$ & IX (variant) & Mariae filius & - \\
\hline S32 & $36 \mathrm{r}$ & $43 \mathrm{v}$ & $\mathrm{F}$ & XVII & - & - \\
\hline S36 & $29 \mathrm{r}$ & $37 \mathrm{r}$ & $\mathrm{E}$ & - & - & De martyribus \\
\hline S39 & $34 \mathrm{r}$ & $42 \mathrm{r}$ & $\mathrm{D}$ & - & Mariae natus & - \\
\hline S49 & $24 \mathrm{v}$ & $32 \mathrm{r}$ & G & IV & Mariae filius & Idem (De BVM) \\
\hline S90 & $35 \mathrm{r}$ & $43 \mathrm{r}$ & G & - & - & - \\
\hline S103 & $30 \mathrm{r}$ & $37 \mathrm{v}$ & $\mathrm{F}$ & VIII & - & De confessoribus \\
\hline S106a & $32 \mathrm{r}$ & $40 \mathrm{r}$ & $\mathrm{F}$ & - & - & Communne \\
\hline S108b & $38 \mathrm{r}$ & $46 \mathrm{r}$ & $\mathrm{F}$ & - & - & - \\
\hline S119a & $21 \mathrm{r}$ & $28 \mathrm{r}$ & $\mathrm{F}$ & - & - & Ad placitum \\
\hline S127a & $26 \mathrm{v}$ & $34 \mathrm{v}$ & $\mathrm{F}$ & - & $\begin{array}{l}\text { Omnes una } \\
\text { carminantes, } \\
\text { Mariae natus }\end{array}$ & Ad placitum \\
\hline S137 & $28 \mathrm{r}$ & $36 \mathrm{r}$ & $\mathrm{E}$ & - & - & Ad placitum \\
\hline S147 & $38 \mathrm{v}$ & $47 \mathrm{r}$ & $\mathrm{E}$ & - & - & - \\
\hline S148 & $30 \mathrm{v}$ & $39 \mathrm{r}$ & $\mathrm{E}$ & - & - & De virginibus \\
\hline S150 & $22 \mathrm{r}$ & $29 \mathrm{r}$ & $\mathrm{E}$ & - & - & Solenne \\
\hline S158 & $20 \mathrm{r}$ & $27 r$ & $\mathrm{D}$ & - & - & Angelicum \\
\hline
\end{tabular}

12 BOSSE, Detlev: Untersuchung einstimmiger mittelalterlicher Melodien zum „Gloria in excelsis Deo". Regensburg, 1955.

13 THANNABAUR, Peter Joseph: Das einstimmige Sanctus der Roemischen Messe in der Handschriftlichen Ueberlieferungen des 11. bis 16. Jahrhunderts. Muenchen, 1962. 


\begin{tabular}{|l|c|c|c|c|c|l|}
\hline Than. & Ca I & Ca II & Modus & LU & Trópus & Rubrika v Ca I \\
\hline S174 & $33 \mathrm{r}$ & $41 \mathrm{r}$ & D & - & - & Ad placitum \\
\hline S177 & $39 \mathrm{v}$ & $48 \mathrm{r}$ & D & XII & - & - \\
\hline S182 & $25 \mathrm{v}$ & $33 \mathrm{r}$ & D & - & - & De BVM \\
\hline S185 & $19 \mathrm{r}$ & $26 \mathrm{r}$ & D & - & - & Summum \\
\hline S203 & $40 \mathrm{v}$ & $48 \mathrm{v}$ & D & II & - & - \\
\hline S215 & $37 \mathrm{v}$ & $45 \mathrm{r}$ & E & - & - & - \\
\hline S223 & $36 \mathrm{v}$ & $44 \mathrm{v}$ & G & XV & - & - \\
\hline
\end{tabular}

Tabulka 5: Spevy Agnus Dei v Ca I a II

\begin{tabular}{|l|l|l|l|c|c|l|}
\hline Sch. $^{14}$ & Ca I & Ca II & Modus & LU & Trópus & Rubrika v Ca I \\
\hline A34 & $24 \mathrm{v}$ & $32 \mathrm{r}$ & F & XVII & - & De BVM \\
\hline A34a & $36 \mathrm{r}$ & $44 \mathrm{r}$ & F & XVII (variant) & - & - \\
\hline A37a & $23 \mathrm{v}$ & $31 \mathrm{r}$ & F & - & - & Ad placitum \\
\hline A42 & $29 \mathrm{v}$ & $37 \mathrm{v}$ & E & - & - & De martyribus \\
\hline A56 & $34 \mathrm{v}$ & $42 \mathrm{v}$ & D & - & - & - \\
\hline A109 & $35 \mathrm{v}$ & $43 \mathrm{v}$ & G & - & - & - \\
\hline A120 & $30 \mathrm{v}$ & $38 \mathrm{v}$ & F & - & - & De confessoribus \\
\hline A124a & $32 \mathrm{v}$ & $40 \mathrm{v}$ & F & - & - & Communne \\
\hline A126b & $38 \mathrm{v}$ & $46 \mathrm{v}$ & F & - & - & - \\
\hline A136 & $25 \mathrm{r}$ & $32 \mathrm{v}$ & tp2 $\uparrow \mathrm{F}$ & IV & - & Idem (De BVM) \\
\hline A141 & $21 \mathrm{v}$ & $29 \mathrm{r}$ & F & - & - & Ad placitum \\
\hline A160 & $27 \mathrm{v}$ & $35 \mathrm{v}$ & F & - & - & Ad placitum \\
\hline A176 & $39 \mathrm{r}$ & $47 \mathrm{v}$ & E & - & - & De virginibus \\
\hline A177 & $31 \mathrm{v}$ & $39 \mathrm{v}$ & E & - & - & Solenne \\
\hline A179 & $22 \mathrm{v}$ & $30 \mathrm{r}$ & E & - & - & Ad placitum \\
\hline A182 & $28 \mathrm{v}$ & $36 \mathrm{v}$ & E & - & - & Angelicum \\
\hline A190 & $20 \mathrm{v}$ & $27 \mathrm{v}$ & D & - & - & Ad placitum \\
\hline A202 & $33 \mathrm{v}$ & $41 \mathrm{v}$ & D & - & - & \\
\hline A209 & $37 \mathrm{r}$ & $45 \mathrm{r}$ & D & XV & - & - \\
\hline A210 & $40 \mathrm{r}$ & $48 \mathrm{r}$ & D & - & - & De BVM \\
\hline A216 & $26 \mathrm{r}$ & $33 \mathrm{v}$ & D & - & - & Summum \\
\hline A226 & $19 \mathrm{v}$ & $26 \mathrm{v}$ & D & II & - & - \\
\hline A249b & $41 \mathrm{r}$ & - & D & - & - & - \\
\hline A258 & $37 \mathrm{v}$ & $45 \mathrm{v}$ & E & - & - & \\
\hline
\end{tabular}

V Ca I sa nachádza 25 melódií Kyrie, 9 Gloria, 24 Sanctus a rovnaký počet Agnus. Ca II uvádza 28 Kyrie, 13 Gloria, 23 Sanctus a 23 Agnus. Tieto počty boli pôvodne vyššie, pretože v súčasnosti majú kódexy defekty práve v pasáži, kde je ordinárium (Ca I - medzi f 1 a f 2, f 40 a f 41, Ca II - medzi f 6 a f 7, f 48 a f 49). ${ }^{15}$

14 SCHILDBACH, Martin: Das einstimmige Agnus Dei und seine handschriftliche Überlieferung vom 10. bis 16. Jahrhundert. [Dizertačná práca.] Erlangen-Nürnberg, 1967.

15 Uvádzaná foliácia pochádza z neskoršieho obdobia a zohladňuje súčasný stav kódexov. 
V oboch rukopisoch je až na menšie (obsahové alebo liturgické) rozdiely v zásade ten istý repertoár. V Ca I sú tri melódie Kyrie (K96, K149a, K217), ktoré nenájdeme v Ca II, naopak, v Ca II je až šest’ melódií Kyrie, ktoré sa nenachádzajú v Ca I (K18, K39, K56, K97, K148?, K217b). V Ca II nájdeme aj o tri melódie Gloria viac ako v Ca I (G12, G24a, G45). Ak ide o spevy Sanctus, repertoár je až na jednu výnimku totožný. V Ca II je o jednu melódiu viac. Ide o melodický variant K29a. Podobne je to pri spevoch Agnus Dei, kde Ca I má jednu melódiu navyše oproti druhému zväzku (A249a). Obidva kódexy teda spolu ponúkajú 31 spevov Kyrie, 12 Gloria, 25 Sanctus a 24 Agnus (Tabulka 6).

Tabulka 6: Prehlad počtu spevov omšového ordinária v košickom prameni

\begin{tabular}{|lr|ll|ll|}
\hline Ca I & & Ca II & & Spolu \\
\hline Kyrie & 25 & Kyrie & 28 & Kyrie & 31 \\
Gloria & 9 & Gloria & 12 & Gloria & 12 \\
Sanctus & 24 & Sanctus & 23 & Sanctus & 25 \\
Agnus & 24 & Agnus & 23 & Agnus & 24 \\
\hline
\end{tabular}

Týmto počtom spevov sa Košický graduál pripodobňuje k uhorskému kódexu s názvom Graduale Francisci de Futhak (dalej GrFu - 30 Kyrie, 16 Gloria, 25 Sanctus a Agnus). ${ }^{16} \mathrm{Iba}$ nižší počet spevov Gloria pripodobňuje tento rukopis k prameňu Graduale Strigoniense (dalej GrStr - 19 Kyrie, 12 Gloria, 12 Sanctus, 10 Agnus). ${ }^{17}$

\section{Melódie typické pre uhorské pramene}

V košickom prameni sa nachádza niekolko spevov omšového ordinária, ktoré sú typické pre uhorskú liturgickú tradíciu:

K201. Tento spev je reprezentačným spevom ostrihomskej tradície, pretože vznikol pravdepodobne v uhorskom prostredí. Nachádza sa v dalších 11 uhorských kódexoch. $^{18}$

S119. Je to další reprezentačný spev ostrihomskej tradície. Adaptácia je uhorského pôvodu a nachádza sa aj v krakovských rukopisoch z 15. storočia. Ide teda o spev, ktorý je známy tak v Uhorsku (9 rukopisov), ako aj v Polsku. ${ }^{19}$ Spev S1 19 tvorí dvojicu s A141. Pol’ské rukopisy však uvádzajú iba Sanctus. V oboch prípadoch ide o adaptáciu melódie responzória Jacet granum určeného na sviatok sv. Tomáša Becketa. ${ }^{20}$

A141. Takisto reprezentačný spev, nachádzajúci sa v dalších siedmich uhorských rukopisoch. ${ }^{21}$

\footnotetext{
16 Cit. podla: SZENDREI, Ref. 9, s. 170.

17 Cit. podla: SZENDREI, Ref. 9, s. 170.

18 KISS, Gábor - CZAGÁNY, Zsuzsa - KLUGSEDER, Robert (eds.): Monumenta Monodica Medii Aevi - Subsidia, VI. : Ordinariums-Gesänge in Mitteleuropa Repertoire-Übersicht und Melodienkatalog. Kassel; Basel; London; New York; Prag : Bärenreiter, 2009, s. 93-94.

19 KISS - CZAGÁNY - KLUGSEDER, Ref. 18, s. 95.

20 KISS - CZAGÁNY - KLUGSEDER, Ref. 18, s. 239.

${ }^{21}$ KISS - CZAGÁNY - KLUGSEDER, Ref. 18, s. 96.
} 


\section{Melodické varianty typické pre uhorskú tradíciu}

Takýchto spevov, ktoré sú variantmi melódií všeobecne známych v Európe, je v graduáli z Košíc viac, avšak niektoré sú prítomné jedine $\mathrm{v}$ tomto prameni a nevieme ich preto identifikovat's uhorskou tradíciou, skôr s jednou jej regionálnou obmenou.

A179a. Variant melódie prítomný v dalších desiatich uhorských prameňoch. ${ }^{22}$

A249b. Variant prítomný v trinástich uhorských kódexoch, medzi iným aj v Ca I, je odvodený od melódie nemeckého pôvodu, ktorú v katalógu Martina Schildbacha možno nájst pod č. 249. V základnej podobe je prítomná aj v jednom uhorskom a jednom polskom prameni. ${ }^{23} \mathrm{~V} \mathrm{Ca}$ I a v dalších štyroch uhorských rukopisoch (Graduale cuiusdam eccl. superioris - dalej GrSup, GrFu, Graduale Wladislai - dalej GrWl, Graduale ecclesiae Brasoviensis - dalej GrBr) tvorí dvojicu s S203, čo nie je zvykom v ostrihomskej tradícii, kde sa spája so Sanctus č. 185 (tak je to v centrálnych prameňoch). Totiž spojenie S203 - A226, ako aj samotná melódia A226 (Vat. II) sú v tejto tradícii neznáme. ${ }^{24}$

Na spolahlivé určenie liturgickej tradície je dôležité všimnút si aj absenciu istých spevov. V Ca napríklad nie je prítomný spev A198, ktorý chýba aj v ostatných uhorských prameňoch. V Ca nie sú ani spevy typické pre uhorsko-české vztahy. ${ }^{25}$

\section{Rubriky a dvojice spevov}

Pre uhorskú tradíciu sú taktiež typické rubriky s informáciami o liturgickom určení jednotlivých dvojíc spevov. Napríklad K16 - G10.1 sa v uhorských rukopisoch uvádza s rubrikou De apostolis. V Ca I sa však K16 spája s G19 a s rubrikou De martyribus, ako to bolo rozšírené skoro v celej Európe, a hlavne v Krakove.

Podobne je to v prípade dvojice spevov K18 - G11, typickej pre uhorské kódexy. V Ca II sa spája K18 s G24a.

Pri K95 v Ca nie je žiadna rubrika, kým v centrálnych uhorských prameňoch sa uvádza Capolna. Takisto pri K97 chýba typická rubrika Minus Capolna.

K144 sa v Ca, tak ako skoro v celej Európe, uvádza s rubrikou Feriale, a nie ako $\mathrm{v}$ centrálnych uhorských kódexoch Dominicale.

Dvojica S103 - A120 sa v uhorskej tradícii používala na sviatky apoštolov, avšak v Ca sú tieto spevy určené na sviatky vyznávačov.

V Ca chýbajú aj zvláštne rubriky Rosomberg, Rosomberg maior pri dvojici spevov S150 - A179. Nachádza sa tu iba rubrika Solenne.

Spev S177 v Ca netvorí dvojicu s A205, ale s A210 a nesprevádza ich rubrika Ad humiliavit, ako je to v centrálnych uhorských rukopisoch.

22 KISS - CZAGÁNY - KLUGSEDER, Ref. 18, s. 97.

23 KISS - CZAGÁNY - KLUGSEDER, Ref. 18, s. 251.

24 Nachádza sa iba v dvoch kódexoch z periférie (Ca, GrWl). KISS - CZAGÁNY - KLUGSEDER, Ref. 18, s. 83.

25 G. Kiss uvádza tieto spevy: S135-A165.1, A11, A43, A137. KISS - CZAGÁNY - KLUGSEDER, Ref. 18, s. 87. 
Netradičná dvojica v uhorských prameňoch S185 - A226 sa v Ca spája s rubrikou Summum. ${ }^{26}$

\section{Melódie neznáme v centrálnej uhorskej tradícii}

K108b. Je to variant Kyrie č. 107 - spevu, ktorý sa vyskytuje v pol'ských rukopisoch z Gniezna, Krakova a Sandomierza (Príklad 1). Melódia v Ca má však jedinečný charakter, preto je označená ako K108b. ${ }^{27}$

Príklad 1: Porovnanie spevov Kyrie 107 a 108b

K107

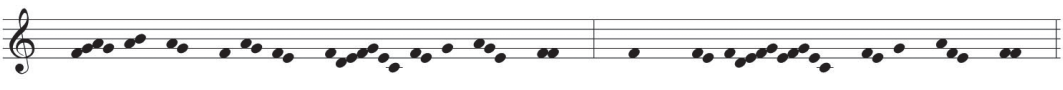

Ky - ri - e

ley - son. Chris - te

ley - son

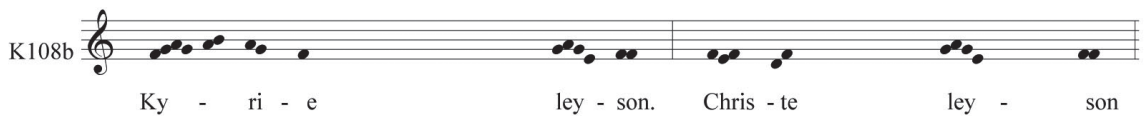

K107
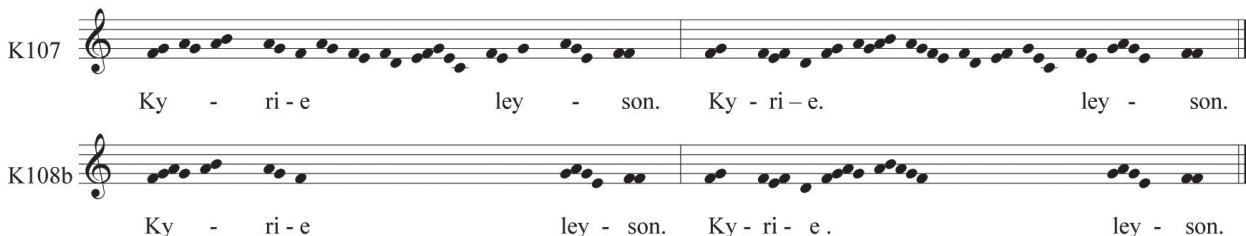

Ďalšie tri spevy z Ca sú takisto súčastou pol’skej liturgickej tradície (rukopisy z Krakova a Vroclavu), avšak dva z nich sú v pol'ských prameňoch (z Krakova) označené ako Ungaricum - K131 a S127. Ozdobná verzia K131a v Ca poukazuje na príbuznost’ s krakovskou podobou tohto spevu (Príklad 2).

Príklad 2: Porovnanie spevov Kyrie 131 a 131a
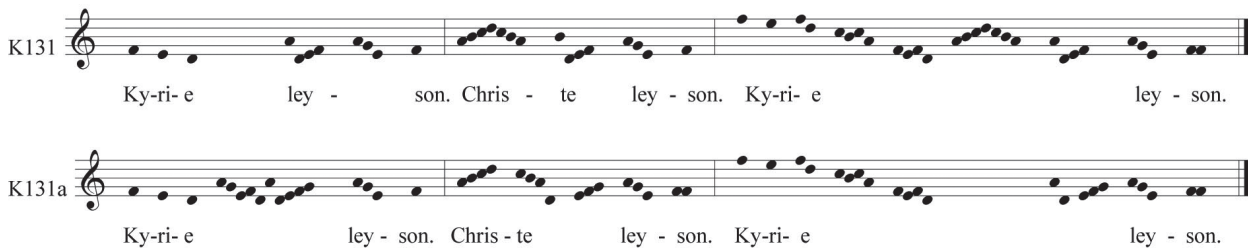

Pol'ské príbuzenstvá prezrádza aj Sanctus č. 127a, ktoré je variantom spevu uvedeného v katalógu Petra Josepha Thannabaura pod č. 127 (Príklad 3). Jerzy Pikulik našiel tento spev s trópmi Omnes una carminantes a Benedictus Mariae natus v deviatich

26 Porov. KISS - CZAGÁNY - KLUGSEDER, Ref. 18, s. 97-98.

27 KISS - CZAGÁNY - KLUGSEDER, Ref. 18, s. 94. 
polských rukopisoch, pričom najstaršie z nich sú z 15 . storočia. ${ }^{28}$ Uvedený trópus sa nachádza aj v AH 47:381, s. 368. Podla autorov tohto monumentálneho diela trópus možno nájst' $v$ nemeckých a českých prameňoch.

Príklad 3: Spev Sanctus 127 s trópom Omnes una carminantes

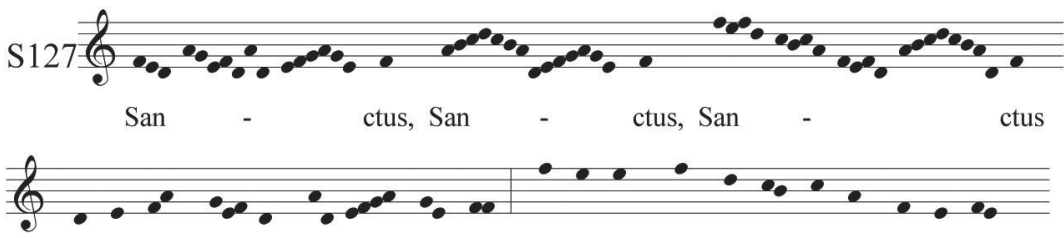

Do-mi-nus De- us Sa - ba - oth. Ple-ni sunt cae- li et ter-ra glo-ri- a

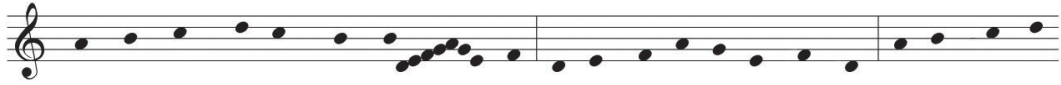

sac-ro sanc-ta sem-per tu - a om-nes u-na car-mi-nan-tes sal-va Chri-ste

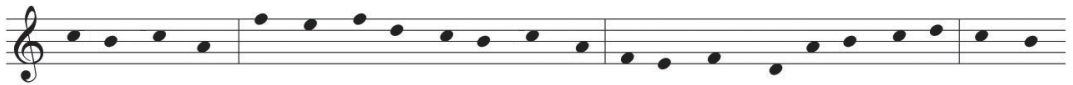

te lau-dan-tes, nunc ho-san-na no-bis man-na Je-su pres-ta-tis sac-ra-ta per haec

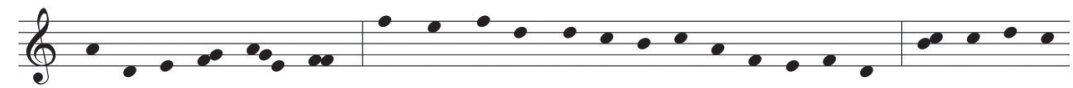

fes-ta in ex-cel-sis. Be-ne- dic-tus Ma-ri-ae na-tus pa-tri gra-tus, qui ve-nit in

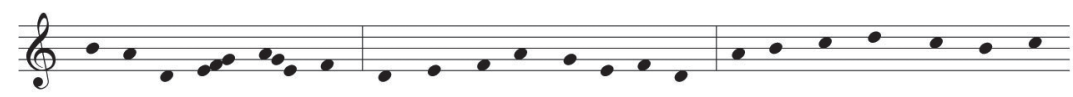

no-mi-ne Do-mi- ni. $O$ dul-ce-do ca-ri-ta-tis Je-su ver-bum sum-mi pa-

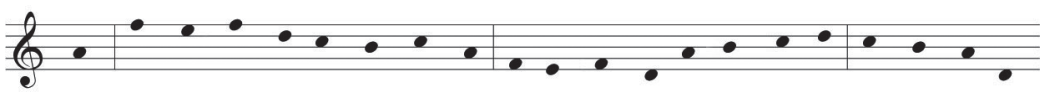

tris nunc ho-san- na pro-cla-man-tes la-be-nan-tes e-mon-dan-tes tan-dem sal-va

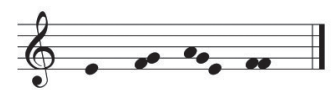

in ex - cel - sis.

Agnus 160 patrí k spevom, ktoré sú rovnako známe v polských i českých rukopisoch. Pikulik uvádza sedem pol'ských prameňov s týmto spevom a d’alších šest', ktoré sú obohatené trópom Miserere Deus vere. $\mathrm{Z}$ uhorských ho poznajú iba dva $\mathrm{GrFu}$ a Ca, kde sa však trópus nenachádza. Najstarší kódex, ktorý daný spev uvádza, je graduál z Augsburgu z prelomu 14. a 15. storočia (Plock, Biblioteka Seminaryjna, ms. b.s.). ${ }^{29}$

K132 sa v Ca spája s G5 a oba spevy sú pravdepodobne určené na sviatky Panny Márie, podobne ako je to v českých a pol'ských rukopisoch. ${ }^{30}$

28 PIKULIK, Ref. 10, s. 231.

29 PIKULIK, Ref. 10, s. 259.

30 KISS - CZAGÁNY - KLUGSEDER, Ref. 18, s. 37-38. 
K149a - tento variant melódie (K149), inak známej a rozšírenej v celom stredoeurópskom priestore (okrem centrálnych uhorských prameňov), podla Gábora Kissa uvádza iba Ca I..$^{31}$

K212a - je variantom melódie (K212) rozšírenej hlavne v Čechách. Daný variant sa nachádza iba $\mathrm{v}$ Ca. ${ }^{32}$ Melódia K212, ktorá sa stala predlohou pre vznik variantu, je adaptáciou antifóny Bethlehem non est minima, ktorá bola súčastou stredovekého modlitbového ofícia na prvú adventnú nedelu počas prímy. ${ }^{33}$

G45 - je spev rozšírený hlavne v českých a čiastočne aj v polských prameňoch. Z uhorských ho uvádza iba druhý diel prezentovaného graduálu.

Dvojica spevov $\$ 90$ - A109 je známejšia v polských rukopisoch, pretože ju uvádzajú v šiestich prípadoch. Najstarší je z prelomu 14. a 15. storočia. Z uhorských ju uvádzajú dva mladšie - GrFu a Ca.

S108b - variant melódie K107, známej v polských rukopisoch z Gniezna, Krakova a Sandomierza. V tejto podobe sa však vyskytuje iba v Ca. Spev S108b tvorí v prezentovanom prameni dvojicu s A126b, variantom známym iba z Ca. Iný variant tejto melódie (126a) možno nájst’ v pol'ských prameňoch z Gniezna (1), Krakova (2) a Sandomierza (1) a v českých prameňoch. ${ }^{34}$

Príklad 4: Porovnanie spevov Agnus Dei 126, 126a z krakovských prameňov a 126b (dve verzie) z Ca

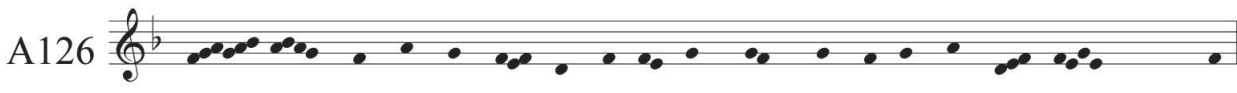

$\mathrm{Ag}$ - nus De- $\mathrm{i}$ qui to - lis pe-ca- ta mun - di mi-se-re-re no - bis.

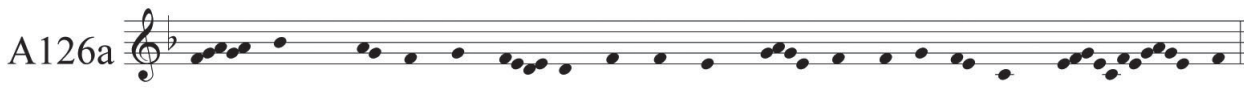

Ag - nus De-i qui to - lis pe-ca-ta mun-di mi-se-re-re no - bis.

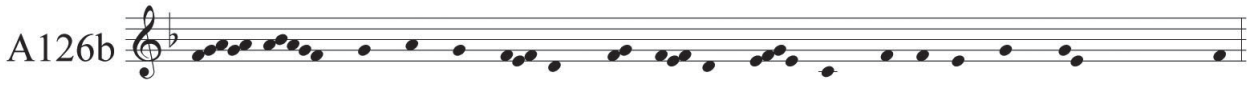

$\mathrm{Ag}$ - nus De-i qui to- lis pe-ca- ta mun-di mi-se-re-re no - bis.

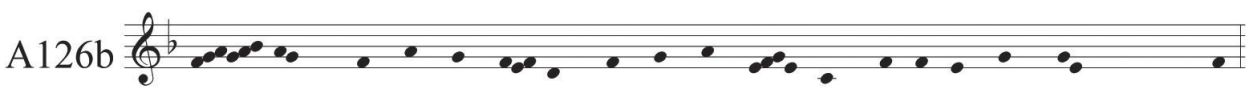

$\mathrm{Ag}$ - nus De-i qui to- lis pe- ca- ta mun-di mi-se-re- re no - bis.

A126

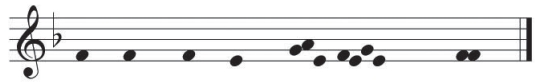

Do-na no-bis pa - cem.

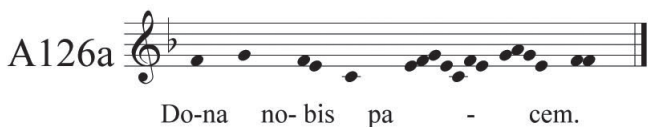

KISS - CZAGÁNY - KLUGSEDER, Ref. 18, s. 96.

32 KISS - CZAGÁNY - KLUGSEDER, Ref. 18, s. 96.

33 DOBSZAY, László - SZENDREI, Janka (eds.): Monumenta Monodica Medii Aevi. Vol. V. Antiphonen im 1.-8. Modus II. Kassel; Basel; London; New York; Prag : Bärenreiter, 1999, s. 620, č. 4218, ISBN 978-3761-814-833.

34 KISS - CZAGÁNY - KLUGSEDER, Ref. 18, s. 236. 
S137 a A182 - je dvojica spevov, ktoré sa neobjavujú v iných uhorských kódexoch. Kým Sanctus bolo rozšírené hlavne v Čechách ${ }^{35}$ a v Pol'sku sa vyskytovalo iba sporadicky, ${ }^{36}$ Agnus bolo zriedkavé aj v Čechách. Je zaujímavé, že spojenie týchto spevov do dvojice je prítomné $\mathrm{v}$ dvoch pol’ských prameňoch $\mathrm{z}$ pohraničných regiónov ( $\mathrm{z}$ Tarnova a Cieszyna). ${ }^{37}$

S147 a A176 sú spevy rozšírené v stredoeurópskom priestore vrátane periférnych oblastí Uhorska. ${ }^{38}$ Ostrihomský liturgický úzus ich nepoznal.

K7 - Táto melódia bola podla katalógu Margaréty Melnickej známa vo francúzskych, talianskych, nemeckých, ale aj českých a pol'ských prameňoch, avšak v reprezentačných uhorských sa vyskytovala iba zriedkavo (Rituale Paulinorum - dalej RitPaul, Missale Paulinorum - dalej Göttw 234, GrFu). Nachádza sa však v rukopisoch $\mathrm{z}$ uhorskej periférie (Graduale Zagrabiense - d’alej GrZagr, Ca). ${ }^{39}$

K68 (= Vat. XIV) - Uvedená melódia bola podla katalógu Melnickej známa vo francúzskych, talianskych, nemeckých, ale aj českých a pol’ských prameňoch, avšak v reprezentačných uhorských sa nevyskytovala. Nachádza sa však v rukopisoch $\mathrm{z}$ uhorskej periférie (GrZagr, GrSup, GrWl, Ca). ${ }^{40}$

K151 (= Vat. XVIII) - Táto melódia bola podla katalógu Melnickej známa v západných, ale aj českých a pol'ských prameňoch, avšak v reprezentačných uhorských sa nevyskytovala. Nachádza sa skôr v rukopisoch z uhorskej periférie (GrSup, GrWl, $\mathrm{GrBr}, \mathrm{Ca}) .{ }^{41}$

G43 - Spev sa vyskytuje v rukopisoch z periférnych uhorských regiónov (GrZagr, GrSup, GrWl, GrBr, Ca). ${ }^{42}$

A226 (= Vat. II) - sa neobjavuje v centrálnych ostrihomských prameňoch (iba v GrWl a Ca). Ide o archaický spev, ktorý sa v nemeckom prostredí spájal so Sanctus č. 203. V Ca a GrWl však tvorí dvojicu so Sanctus č. 185, čo je variant S203. Táto dvojica S185 - A226 velmi často vystupuje v pol’ských kódexoch (krakovských, gnieznenských a vroclavských) a objavuje sa aj v pražských. ${ }^{43}$

\section{Spevy známe zároveň v uhorskej i v polskej tradícii}

S39 sa podla Kissa nachádza v šiestich uhorských a podla Pikulika v sedemnástich polských prameňoch, pričom $\mathrm{v}$ dvoch $\mathrm{z}$ nich je označené rubrikou Ungaricum. Najstarší uhorský rukopis je z roku $1463(\mathrm{GrFu})$ a najstarší pol'ský z obdobia okolo roku $1460{ }^{44}$

To isté platí pre Agnus č. 56, ktoré tvorí dvojicu s S39 a tiež patrí k spevom, ktoré sú spoločné pre uhorskú i pol’skú liturgickú tradíciu.

\footnotetext{
KISS - CZAGÁNY - KLUGSEDER, Ref. 18, s. 213.

PIKULIK, Ref. 10, s. 239.

PIKULIK, Ref. 10, s. 239 a 265 melódia č. 44.

KISS - CZAGÁNY - KLUGSEDER, Ref. 18, s. 214-215, 242.

KISS - CZAGÁNY - KLUGSEDER, Ref. 18, s. 53.

KISS - CZAGÁNY - KLUGSEDER, Ref. 18, s. 53.

KISS - CZAGÁNY - KLUGSEDER, Ref. 18, s. 53.

KISS - CZAGÁNY - KLUGSEDER, Ref. 18, s. 53 - 54.

43 Podla databázy, ktorú uvádza G. Kiss. Porov. KISS - CZAGÁNY - KLUGSEDER, Ref. 18, s. 137-160.

44 PIKULIK, Ref. 10, s. 230; KISS - CZAGÁNY - KLUGSEDER, Ref. 18, s. 201.
} 
Spevy S119 - A141, S127a - A160 a S148 - A177 takisto patria k spoločnej uhorsko-polskej tradícii.

Dvojica S148 - A177, v Ca určená na sviatky panien, je známa z ôsmich uhorských kódexov, pričom najstarší je GrStr (1500). Pikulik ju našiel v piatich, z ktorých najstarší zápis je zo začiatku 16. storočia. ${ }^{45}$

\section{Spevy známe v stredoeurópskom priestore}

Ide o spevy, ktoré vznikli v niektorej zo stredoeurópskych krajín a v tomto priestore sa aj rozšírili (s výnimkou niektorých, ktoré sa dostali napríklad aj do Talianska). Nemeckého pôvodu sú spevy K78, K132, G5, G48, S215. Nemecký pôvod má aj K126, ktoré okrem Ca z uhorských rukopisov uvádzajú iba dva (El, GrBr). Oblúbený bol aj $\mathrm{v}$ pol'ských rukopisoch.

Český pôvod má S185. Ide o variant spevu Sanctus č. 203 (Vat. II), ktorý sa tiež nachádza v Ca. Thannabaur obidva spevy umiestnil vo svojom katalógu s rôznymi číslami, nevidiac ich podobnost'. S185 vzniklo pravdepodobne v Prahe a rýchlo sa dostalo do nemeckých, uhorských a pol’ských kódexov.

Francúzske, talianske, cisterské vplyvy prezrádza K95 (Vat. VIII). Bolo oblúbené v uhorských rukopisoch, tak centrálnych, ako aj regionálnych (GrFu, Graduale Agriense ex Gyöngyöspata - d’alej $\mathrm{GrPa}$ ), avšak skoro neznáme v pol'ských a českých prameňoch. ${ }^{46}$

\section{Spevy celoeurópskeho repertoáru}

V Ca sa nachádza pomerne vel'ká skupina spevov, ktoré patria k základu európskeho repertoáru spevov ordinária. Ide teda o spevy všeobecne rozšírené. Mnohé z nich sa napokon stali súčastou Editio Vaticana. Ide o 11 Kyrie, 7 Gloria, 7 Sanctus a 6 Agnus (Tabulka 7).

Tabulka 7: Európsky repertoár spevov Kyrie v Ca

\begin{tabular}{|l|c|}
\hline \multicolumn{1}{|c|}{ Č. } & Vat. \\
\hline K16 & XI \\
\hline K18 & IV \\
\hline K39 & I \\
\hline K48 & II \\
\hline K58a & XII (variant) \\
\hline K78 & V \\
\hline K95 & Sanctus Vat. VIII \\
\hline K132 & Ad libitum VIII \\
\hline K144 & - \\
\hline K171 & IX \\
\hline K217 & XVI \\
\hline
\end{tabular}

45 PIKULIK, Ref. 10, s. 237.

46 KISS - CZAGÁNY - KLUGSEDER, Ref. 18, s. 54. 
K48 je všeobecne rozšírený spev. V Ca je uvedený trikrát. Raz s trópom Fons bonitatis, druhýkrát s mariánskym trópom Virginitatis amator a tretíkrát s trópom Sacerdos sume. V̌̌etky tri verzie sú známe v uhorských i polských kódexoch.

Tabulka 8: Európsky repertoár spevov Gloria, Sanctus a Agnus v Ca

\begin{tabular}{|l|c|}
\hline \multicolumn{1}{|c|}{ Č. } & Vat. \\
\hline G11 & XIV \\
\hline G12 & I \\
\hline G19 & II \\
\hline G23 & IX \\
\hline G24 & Ad libitum I \\
\hline G43 & XV \\
\hline G56 & IV \\
\hline
\end{tabular}

\begin{tabular}{|l|c|}
\hline \multicolumn{1}{|c|}{ Č. } & Vat. \\
\hline S29 & IX \\
\hline S32 & XVII \\
\hline S49 & IV \\
\hline S103 & VIII \\
\hline S177 & XII \\
\hline S203 & II \\
\hline S223 & XV \\
\hline
\end{tabular}

\begin{tabular}{|l|c|}
\hline \multicolumn{1}{|c|}{ Č. } & Vat. \\
\hline A34 & XVII \\
\hline A120 & - \\
\hline A136 & IV \\
\hline A209 & XV \\
\hline A210 & - \\
\hline A226 & II \\
\hline
\end{tabular}

\section{Modálna štruktúra spevov}

Už autori prvých katalógov spevov omšového ordinária si všimli, že využívanie jednotlivých modov pri kompozícii týchto spevov závisí od regionálnych a časových faktorov. Kým modus $D$ sa využíval rovnomerne v celej stredovekej Európe, modus $G$ preferovali v Taliansku a mody $E$ a $F$ v Nemecku a v stredoeurópskych krajinách. Tieto modálne preferencie sú viditelné pri zohladnení celého repertoáru (Tabulka 9). 
Tabulka 9: Modálne riešenia všetkých spevov omšového ordinária v Ca

\begin{tabular}{|c|c|c|}
\hline Modus & Spevy & Počet \\
\hline$D$ & $\begin{array}{l}\text { K16, K18, K171, K68, K201, K217, K217a, K217b, } \\
\text { G19, } \\
\text { S39, S158, S174, S177, S182, S185, S203, } \\
\text { A56, A190, A202, A209, A210, A216, A226, A249b, }\end{array}$ & 24 \\
\hline$E$ & $\begin{array}{l}\text { K7, K12, K48, K144, K148, K149, K149a, K151, K212a, } \\
\text { G11, G43, G45, G48, G56, } \\
\text { S36, S137, S147, S148, S150, S215, } \\
\text { A42, A176, A177, A179, A182, A258 }\end{array}$ & 26 \\
\hline$F$ & $\begin{array}{l}\text { K56, K96, K97, K107, K108, K111, K126, K131a, K132, } \\
\text { G5, G37, } \\
\text { S19a, S29a, S32, S103, S106a, S108b, S119a, S127a, } \\
\text { A34, A34a, A37a, A120, A124, A126b, A136, A141, A160 }\end{array}$ & 29 \\
\hline G & $\begin{array}{l}\text { K39, K58a, K78, } \\
\text { G12, G21, G23, G24a, } \\
\text { S49, S90, S223, } \\
\text { A109 }\end{array}$ & 11 \\
\hline
\end{tabular}

Markantnejšie sú však vtedy, ked’ porovnáme pomer využívaných modov v rámci regionálnych spevov. Spevy v mode $G$ tu ani nevystupujú, naopak, modus $E$ sa ukazuje ako vel'mi oblúbený (Tabulka 10).

Tabulka 10: Modálne riešenia regionálnych spevov omšového ordinária v Ca

\begin{tabular}{|c|l|c|}
\hline Modus & Spevy & Počet \\
\hline$D$ & S39, S158, S174, S182, S185, S203 & 6 \\
\hline \multirow{2}{*}{$E$} & K148, K149, & 10 \\
& G45, G48, & \\
\hline$F$ & S36, S137, S147, S148, S150, S215, & 7 \\
\hline
\end{tabular}

Charles M. Atkinson a Gábor Kiss nazývajú tieto melódie pojmom „piesňová E-melodika" (liedhafte E-Melodik). ${ }^{47}$ Pre tieto spevy je typická spevná melodika s terciovými postupmi, velkými skokmi a opakujúcimi sa ustálenými melodickými formulami (napríklad na začiatku motív efed), z ktorých je postavená celá skupina neskorostredovekých spevov (Príklad 5). G. Kiss v rámci tejto vel'kej skupiny vymedzuje ešte dve podskupiny. Do prvej umiestňuje spevy, ktoré majú zjavné spoločné prvky, do druhej spevy, kde sú podobnosti menej nápadné, avšak konštatuje, že hranica medzi tými skupinami nie je vždy zrejmá a jednoznačná. Tento typ melodiky vznikol

${ }_{47}$ ATKINSON, Charles Mercer: Agnus Dei. In: BLUME, Friedrich - FINSCHER, Ludwig (eds.): Die Musik in Geschichte und Gegenwart : Sachteil. Vol. 1. Kassel Basel; New York; Prag, 1994, s. 272; KISS, Gábor: The 'liedhafte E-Melodik' In: Studia Musicologica Academiae Scientiarum Hungariae. [online], roč. 40, 1999, č. 4, s. 315-324. [cit. 13. 11. 2021]. Dostupné na internete: www.jstor.org/stable/902501. 
v 13. storočí v juhonemeckom a českom prostredí, odkial' sa rozšíril do celej strednej Európy. ${ }^{48}$

Príklad 5: Piesňová E-melodika v Kyrie 149, Sanctus 150 a Agnus 177 z Ca
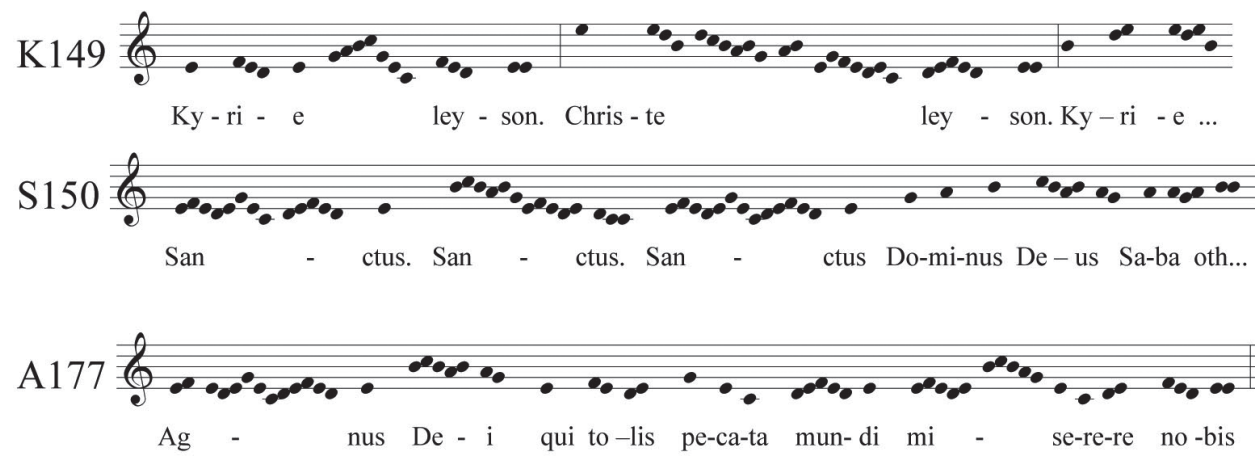

\section{Trópy v spevoch omšového ordinária}

Kyrie. Fons bonitatis (K48) (I/1, II/1v). Ide o trópus, ktorý má svoj pôvod v severnom Francúzsku, odkial' sa rozšíril do celej Európy a v 12. storočí bol už všeobecne známy. Z uhorských prameňov ho uvádzajú ešte d’alšie dva: $\mathrm{GrFu}$ dodatok a GrPa, f. 132v. ${ }^{49}$ V Ca sa nachádza tzv. krátka forma trópu s tromi strofami, ktorá sa všeobecne používala od 14. storočia. ${ }^{50}$ Nadväzujúc na publikáciu Hany Vlhovej-Wörnerovej môžeme túto formu označit' schémou A1 B3 C3, pričom ide o tieto texty: A1 - Fons bonitatis, B3 - Unice Dei Patris genite, C3 - Ignis divine. Takýto výber strof trópu majú aj tri pražské pramene. ${ }^{51}$ Oproti publikovanej verzii v Ca je v C3, v. 4 textový variant decantare namiesto proclamare, čo sa $\mathrm{v}$ českých prameňoch nevyskytuje.

Kyrie. Virginitatis amator (K48) (II/26). Ide o kontrafakt spevu Kyrie. Fons bonitatis, ktorý obsahujú už severofrancúzske a anglické pramene z 12. storočia. V Ca má krátku formu s jednou strofou pri každej aklamácii: A - Virginitatis amator, B2 - Aye gigas fortis, C1 - Qui incarnatus. Z českých rukopisov takúto formu uvedeného trópu

48 KISS - CZAGÁNY - KLUGSEDER, Ref. 18, s. 90.

49 SZENDREI, Janka: Tropenbestand der ungarischen Handschriften. In: DOBSZAY, László (ed.): Cantus Planus, Papers Read at the Third Meeting of the International Musicological Society Study Group, Tihany, Hungary, 19-24 September 1988. Budapest : Hungarian Academy of Sciences, Institute for Musicology, 1990, s. 317.

50 Krátka forma sa líši od pôvodnej - dlhej - v tom, že namiesto troch strof pri každej litániovej aklamácii (Kyrie A1 eleison, Kyrie A2 eleison, Kyrie A3 eleison; Christe B1 eleison, Christe B2 eleison, Christe B3 eleison; Kyrie C1 eleison, Kyrie C2 eleison, Kyrie C3 eleison) je iba jedna strofa trópu, pretože sa už upustilo od trojnásobného spievania každej aklamácie. Porov. VLHOVÁ-WÖRNER, Hana (ed.): Repertorium troporum Bohemiae medii aevi. Vol. II. Tropi ordinarii missae. Ed. Praha : Bärenreiter, 2006, s. 116, 194.

${ }^{51}$ VLHOVÁ-WÖRNER, Ref. 50, s. 116, 194. 
má len jeden. ${ }^{52}$ Textový variant virili (B2, v. 12) sa nevyskytuje v českých prameňoch. Trópus obsahujú dva uhorské pramene: $\mathrm{GrFu}$, dodatok a $\mathrm{GrPa}, \mathrm{f} .132 .{ }^{53}$

Kyrie. Sacerdos summe (K48) (I/1v). V rukopise je zápis textu bez nôt. Je to kontrafakt melódie Kyrie. Fons bonitatis, ktorý bol známy v južnom Nemecku, Taliansku a v Čechách od 14. storočia. V Ca je uvedená krátka forma trópu so štruktúrou A1 - Sacerdos summe, B1 - Hodie... tali specie, C1 - Qui tibi novum. Toto zloženie strof sa nachádza v dvoch českých prameňoch. ${ }^{54}$ Textový variant v B $1, \mathrm{v} .4-5-$ ut processit sacra de virgine / pro nobis moriens in cruce - nie je prítomný v českých prameňoch, avšak je známy z uhorského prameňa $\mathrm{GrPa} .{ }^{55}$ Okrem toho sa trópus nachádza aj v $\mathrm{GrFu}$, $\mathrm{v}$ dodatku. ${ }^{56}$

Kyrie. Magne Deus (K78) (I/1, II/1). Trópus bol rozšírený hlavne v stredoeurópskych krajinách a uvádzajú ho pramene zo 14. - 16. storočia. Podla publikácie Vlhovej-Wörnerovej môžeme štruktúru trópu vyjadrit’ schémou A1 - Magne Deus, B1 - Geniteque, C1 - Cuius natus. Takúto stavbu Vlhová-Wörnerová našla v piatich českých prameňoch. ${ }^{57}$ Spev bol populárny aj v Uhorsku, o čom svedčí jeho pomerne častý výskyt v liturgických knihách. ${ }^{58}$

Spiritus et alme (G23) (I/2v, II/8v), mariánsky trópus, ktorý bol od 13. storočia všeobecne rozšírený a známy. Skladá sa zo šiestich interpolácií do dlhého textu hymnu Gloria (A - F). Podla publikácie Vlhovej-Wörnerovej by sa dala štruktúra trópu v Ca vyjadrit’ schémou ABCDFE, čo vyjadruje, že dva posledné elementy trópu sú prestavené. Túto štruktúru spolu s ozdobnejšou melódiou má trópus vo väčšine českých prameňov. ${ }^{59}$ Okrem Ca trópus obsahuje dalších pät uhorských prameňov. ${ }^{60}$ Najstarší z nich - MNStr - ho uvádza v štruktúre ACDFE, teda element B v ňom chýba.

Mariae filius (S29, S49) (I/24, 25, II/31v, 32v). Je to vel'mi krátka interpolácia, ktorá má síce v oboch spevoch rovnaký text, ale inú melodickú líniu. Nachádza sa ešte v d’alších troch uhorských prameňoch. ${ }^{61}$

Mariae natus (S127a, S39) (I/27, 34, II/42). Je aj v dvoch d’alších uhorských prameňoch. ${ }^{62}$

Omnes una carminantes (S127a) (I/27, II/34v). Tento trópus sa, ked' hovoríme o uhorských prameňoch, nachádza iba v Ca. ${ }^{63}$ Jeho výskyt je však zdokumentovaný v križiackych prameňoch. ${ }^{64}$

52 Je to premonštrátsky graduál z obce Schlägl (Drkolná). Porov. VLHOVÁ-WÖRNER, Ref. 50, s. 151-152.

53 SZENDREI, Ref. 49, s. 317.

54 VLHOVÁ-WÖRNER, Ref. 50, s. 147, 250-251.

55 AH 47:101, s. 162.

56 SZENDREI, Tropenbestand, c.d., s. 317.

57 VLHOVÁ-WÖRNER, Ref. 50, s. 128-129, 207.

58 Okrem Ca ho J. Szendrei našla v dalších štyroch prameňoch. SZENDREI, Ref. 49, s. 317.

59 VLHOVÁ-WÖRNER, Ref. 50, s. 164-165, 243-245.

60 SZENDREI, Ref. 49 , s. 317.

${ }_{61}$ SZENDREI, Ref. 49, s. 317.

62 SZENDREI, Ref. 49, s. 317.

63 SZENDREI, Ref. 49, s. 317.

64 Napr. v Cantionale, sign. Ms.Mar.F.406 z Bazyliki Mariackiej v Gdansku. 


\section{Záver}

Obidva zväzky Košického graduálu spolu ponúkajú 92 spevov, ktoré zaradujeme do kategórie spevov omšového ordinária, z čoho je 31 spevov Kyrie, 12 Gloria, 25 Sanctus a 24 Agnus. Väčšina $\mathrm{z}$ nich je uvedená v obidvoch rukopisoch a pochádza zo spoločného európskeho repertoárového dedičstva. Sú tu však aj spevy, ktoré majú regionálny pôvod alebo aspoň regionálny charakter vd’aka typickej melodickej variantnosti. Uhorskú, respektíve spoločnú pol'sko-uhorskú tradíciu zastupuje spolu devät spevov, čo je približne jedna desatina všetkých spevov omšového ordinária. Druhú skupinu regionálnych prvkov tvoria spevy z iných stredoeurópskych tradícií (českej, pol’skej, nemeckej), ktorých je spolu dvanást'. V skúmanom graduáli je pomerne velký počet takých spevov, ktoré sú variantmi melódií všeobecne rozšírených v Európe, avšak sú známe jedine z tohto prameňa.

Z vyššie uvedených skutočností vyplýva, že Kyriale v Ca je síce vystavané na základe ostrihomskej hudobno-liturgickej tradície, avšak so silnými vplyvmi okolitých liturgických centier a ich zvykov, hlavne krakovského a čiastočne iného západného, ktorý sa nám zatial' nepodarilo identifikovat'. Aj v tejto oblasti výskumy potvrdili, že Ca patrí k skupine regionálnych kódexov, ktoré majú vo vztahu k hlavnej ostrihomskej liturgicko-hudobnej tradícii skôr periférny charakter. Ide však o isté obohatenie danej uhorskej tradície, vd’aka čomu má Košický graduál jedinečný a neopakovatelný charakter, a tým aj velkú historickú a umeleckú hodnotu.

Štúdia je súčastou riešenia projektov: VEGA 2/0006/21 „Transregionálne vztahy prameňov duchovnej a svetskej hudby z územia Slovenska v 12. - 17. storočí" a APVV-19-0043 „CANTUS PLANUS na Slovensku: lokálne prvky - transregionálne vztahy“.

\section{Skratky použitých porovnávacích prameňov:}

Ca I Graduale Cassoviense Vol. I. saec. XVI/in. Budapest, Országos Széchényi Könyvtár, sign. Clmae 172a.

Ca II Graduale Cassoviense Vol. II. saec. XVI/in. Budapest, Országos Széchényi Könyvtár, sign. Clmae 172b. El - Codex Eligius 1432. Budapest, Országos Széchényi Könyvtár, sign. Clmae 377.

$\mathrm{GrBr}$ Graduale ecclesiae Brassoviensis saec. XVI/in, Sibiu, Muzeul Brukenthal, sign. Ms. 759. Prístupné na internete v Hungarian Chant Database: http://gradualia.eu/source/1344.

GrSup Graduale cuiusdam ecclesiae Hungariae superioris saec. XIV, Alba Iulia, Bibliotheca Batthyanyana, sign. R. I. 96; Szendrei C-49.

$\mathrm{GrFu}$ Graduale Francisci de Futhak, 1463. Istanbul, Topkap Seray, sign. 2429; Szendrei C-45.

GrPa Graduale Agriense? ex Gyöngyöspata saec. XVI/med, Budapest, Országos Széchényi Könyvtár, sign. Fol. Lat. 3522; Szendrei C-102.

GrStr Graduale Strigoniense alebo Bakócz Gradual. 14./15. storočie. Esztergomi Főszékesegyházi Könyvtár (Ostrihom, Katedrálna knižnica), sign. MSS I.1. Vydanie: SZENDREI, J. - SAS, A. - FERENCZI, I. (ed.): Musicalia Danubiana 12. Vol. * a ${ }^{* \star}$. Budapest : Magyar tudományos akadémia, Zenetudományi intézet, 1993. ISBN $9637074260,9637074279$.

GrWl Graduale Wladislai II. saec. XVI/in, Esztergom, Fõszékesegyházi Könyvtár, sign. Mss. I. 3.

GrZagr Záhrebský graduál. 14. - 15. storočie. Záhreb, Archiv Jugoslavenske Akademije Znanosti i Umjetnosti, sign. III d 182.

MNStr Missale Notatum Strigoniense. Pred 1314. Bratislava, Archív mesta Bratislava, sign. EC Lad. 3. a EL 18. Vydanie: SZENDREI, J. - RYBARIČ, R. (ed.): Musicalia Danubiana 1. Budapest : Magyar tudományos akadémia, Zenetudományi intézet, 1982. ISBN 963-01-41426. 


\section{Použitá literatúra:}

ATKINSON, Charles Mercer: Agnus Dei. In: BLUME, Friedrich - FINSCHER, Ludwig (eds.): Die Musik in Geschichte und Gegenwart: Sachteil. Zv. 1. Kassel; Basel; New York; Prag, 1994, s. 272.

BALOGH, Jolán: Varadinum, Várad vára. In: Müvészettörténeti Füzetek 13/2. Budapest : Akadémiai Kiadó, 1982. ISBN 963-05-2900-9.

BERKOVITS, Ilona: A Kassai-graduale és a XVI. századi kassai festészet. In: Emlékkönyv Gerevich Tibor születésének 60. Évfordulójára. Budapest, 1942, s. 68-88;

BOSSE, Detlev: Untersuchung einstimmiger mittelalterlicher Melodien zum „Gloria in excelsis Deo“. [Dizertačná práca.] Regensburg, 1955.

DOBSZAY, László - SZENDREI, Janka (eds.): Monumenta Monodica Medii Aevi. Vol. V. Antiphonen im 1.-8. Modus II. Kassel; Basel; London; New York; Prag : Bärenreiter, 1999. ISBN 978-3761-814-833.

GÜNTHEROVÁ, Alžbeta - MIŠIANIK, Ján: Stredoveká knižná malba na Slovensku. Bratislava : Slovenské vydavatel'stvo krásnej literatúry, 1961, 197 s.

HOFMANN, Edit: A Nemzeti Múzeum Széchényi Könyvtárának illuminált kéziratai. In: Magyar Könyvszemle, 1927, č. 34, zošit 1-2, s. 1-43.

KISS, Gábor - CZAGÁNY, Zsuzsa - KLUGSEDER, Robert (eds.): Monumenta Monodica Medii Aevi - Subsidia, VI. : Ordinariums-Gesänge in Mitteleuropa Repertoire-Übersicht und Melodienkatalog. Kassel; Basel; London; New York; Prag : Bärenreiter, 2009, 277 s. ISBN 978-3761-822-180.

KISS, Gábor: A true 'Central European' manuscript: the Graduale Cassoviense from 1518. In: ADAMKO, Rastislav (ed.): Musica Mediaeva Liturgica II. : Zborník príspevkov z muzikologickej konferencie. Ružomberok : Verbum, 2016, s. 77-89. ISBN 978-80-561-0356-2.

KISS, Gábor: The 'liedhafte E-Melodik'. In: Studia Musicologica Academiae Scientiarum Hungariae. [online] 1999, č. 40, zošit 4, s. 315-324. [cit. 13. 11. 2021.] Dostupné na internete: www.jstor.org/stable/902501.

LANDWEHR-MELNICKI, Margaretha: Das einstimmige Kyrie des lateinischen Mittelalters. [Dizertačná práca.] Regensburg, 1955.

PIKULIK, Jerzy: Indeks śpiewów Ordinarium missae w graduałach polskich do $1600 \mathrm{r}$. In: Muzyka religijna w Polsce. Zv. 2. Warszawa, 1978, s. 139-271. b. ISBN.

SCHILDBACH, Martin: Das einstimmige Agnus Dei und seine handschriftliche Überlieferung vom 10. bis 16. Jahrhundert. [Dizertačná práca.] Erlangen-Nürnberg, 1967.

SZENDREI, Janka: Graduale Strigoniense I. : Musicalia Danubiana Vol. 12*. Budapest : Magyar Tudományos Akadémia Zenetudomány Intézet, 1993, 220 s. ISBN 963-7074-26-0.

SZENDREI, Janka: Tropenbestand der ungarischen Handschriften. In: DOBSZAY, László (ed.): Cantus Planus, Papers read at the Third Meeting of the International Musicological Society Study Group, Tihany, Hungary, 19-24 September 1988. Budapest : Hungarian Academy of Sciences, Institute for Musicology, 1990, s. 297-325. ISBN 963-7516-56-5.

THANNABAUR, Peter Joseph: Das einstimmige Sanctus der Roemischen Messe in der Handschriftlichen Ueberlieferungen des 11. bis 16. Jahrhunderts. [Dizertačná práca.] Muenchen, 1962.

VESELOVSKÁ, Eva: Catalogus fragmentorum cum notis musicis medii aevi e civitatibus Modra et Sanctus Georgius I. Bratislava : Institut für Musikwissenschaft der Slovakischen Akademie der Wissenschaften, 2008, 202 s. ISBN 987-80-89135-22-6.

VLHOVÁ-WÖRNER, Hana (ed.): Repertorium troporum Bohemiae medii aevi. Vol. II. Tropi ordinarii missae. Ed.. Praha : Bärenreiter, 2006, 272 s. ISMN M-2601-0331-3.

ZUBKO, Peter: Kult Svätej Krvi v Košiciach : Rozprávanie o stratených stredovekých relikviách. Košice : Viliam Ščiavnický, 2012, 127 s. ISBN 978-80-971061-1-9. 


\section{Summary}

\section{Chants from the Ordinary of the Mass in the Graduale Cassoviense MANUSCRIPTS}

The two volumes of the Košice Gradual together offer 92 chants which we consign to the category of chants of the Mass Ordinary. Of these there are 31 chants of the Kyrie, 12 of the Gloria, 25 of the Sanctus and 24 of the Agnus. Most of them are featured in both manuscripts and derive from a common European repertorial heritage. There are also, however, chants that have a regional origin or at least a regional character, thanks to a typical melodic variation. In total nine chants, representing roughly one-tenth of all chants from the Mass Ordinary, represent a Hungarian or Polish-Hungarian tradition. A second group of regional elements, twelve in total, comprises chants from other Central European traditions (Czech, Polish, German). The Košice Gradual contains a relatively large number of chants which are variants of melodies generally known in Europe but are themselves known only from this single source.

From the above-mentioned facts, it follows that while the Kyriale in Ca is constructed on the basis of the Estergom musico-liturgical tradition, it is nonetheless strongly influenced by surrounding liturgical centres and their customs: principally by Krakow, and partially from another western centre which hitherto we have not managed to identify. Research in this field has also confirmed that $\mathrm{Ca}$ is one of a group of regional codices which have rather a peripheral character in relation to the main Estergom liturgico-musical tradition. This involves, however, a certain enrichment of the given Hungarian tradition, thanks to which the Košice Gradual has a unique and inimitable character and is of major historical and artistic value. 